\title{
Social skills contributing to the behaviors of physicians, nurses, and paramedics in various professional situations
}

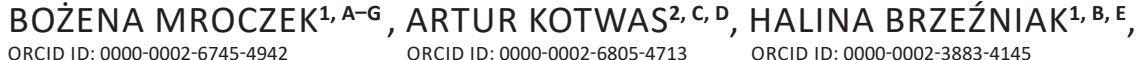

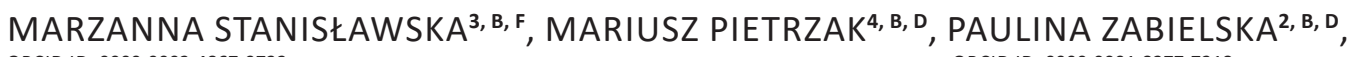 \\ ORCID ID: 0000-0002-4867-9732 $\quad$ ORCID ID: 0000-0001-8377-7218 \\ WERONIKA WOLIŃSKA ${ }^{1, D, E}$, DONATA KURPAS 5, D, E \\ ORCID ID: 0000-0002-3358-8280 \\ ${ }^{1}$ Department of Humanities in Medicine, Pomeranian Medical University, Szczecin, Poland \\ ${ }^{2}$ Department of Social Medicine, Pomeranian Medical University, Szczecin, Poland \\ ${ }^{3}$ Department of Nursing, Pomeranian Medical University, Szczecin, Poland \\ ${ }^{4}$ Department of Internal Diseases and Diabetology with Endocrinology Unit, Independent Public Provincial \\ Integrated Hospital, Szczecin, Poland \\ ${ }^{5}$ Department of Family Medicine, Wrocław Medical University, Poland
}

A - Study Design, B - Data Collection, C - Statistical Analysis, D - Data Interpretation, E - Manuscript Preparation, F - Literature Search, G - Funds Collection

Summary Background. Efficient functioning at work depends on social/emotional competence, understood as a set of complex skills that determine the effectiveness of behaviors in various professional and social situations.

Objectives. The aim of this study was to determine the social competence of physicians, nurses, and paramedics with regard to sociodemographic contributors and social training.

Material and methods. The study involved 303 medical workers, including 90 physicians (29.7\%), 112 nurses (36.96\%), and 101 paramedics (33.3\%). The Social Competence Questionnaire (SCQ) and a questionnaire developed by the researchers were completed. The diagnostic questions included three types of situations: intimate situations (I), situations involving social exposure (SE), and situations demanding assertiveness $(A)$.

Results. The majority of healthcare workers had average general social competence, over one-fifth had high competence, and one-sixth had low competence. Low competence in social exposure situations (SE) was observed in nearly one-fourth of the participants. One in six respondents had low competence in situations demanding close interpersonal contact (I) and assertiveness (A). Medical workers aged 45 years and up had lower general competence as well as lower I and SE competence. Social training associated with scientific and social activity develops SE competence in physicians and A competence in paramedics.

Conclusions. The low and average scores for social competence achieved by physicians, nurses, and paramedics demonstrate the need for more social training, especially involving professionals in scientific activity and the education of medical staff and various social groups.

Key words: social skills, sensitivity training groups, health personnel.

Mroczek B, Kotwas A, Brzeźniak H, Stanisławska M, Pietrzak M, Zabielska P, Wolińska W, Kurpas D. Social skills contributing to the behaviors of physicians, nurses, and paramedics in various professional situations. Fam Med Prim Care Rev 2020; 22(2): 126-132, doi: https://doi.org/10.5114/fmpcr.2020.95321.

\section{Background}

The measurement and validation of professional and social competences of medical workers may help provide patients with safe, factual, high-quality care. Validating these competences can contribute to better clinical results for patients and can reduce the costs of providing healthcare [1-10]. According to White, social competence denotes the ability of a person to interact effectively with others; it is acquired not only through the process of maturation, but also through the process of learning [11]. Argyle perceives social competence - also called social efficiency - as the ability to exert the desired influence on other people in social situations, or as an individual's capability of defining his or her professional and personal goals [12]. Other authors propose similar definitions, indicating that competence is a set of abilities that allow individuals to cope successfully with various situations. These abilities manifest as specific behaviors in social situations [5, 6, 13-15].
In many studies, the term "social competence" describes communicative abilities, relational competence, and social and adaptive skills. These are particularly important in the case of emotional labor, such as healthcare services, which are provided under the specific situations of patients and medical workers [16-18]. One indicator of competence is the effectiveness of people's functioning in real social situations, which relates to their efficiency in achieving their goals, their ability to build interpersonal bonds, the lack of excessive psychological and psychophysiological costs associated with social relationships, and adherence to behaviors and social standards [19, 20]. Regardless of differences in the approach to social competence, researchers regard it as an aptitude that determines how effectively a person functions socially and professionally $[12,18$, 21]. Individual differences in the level of social competence are associated with the effectiveness, intensity, and type of social activity $[11,14,15,22,23]$. 
A person is subject to social training during contact with other people in everyday social situations, such as social and professional activities, carrying out organizational functions, and caring for others [24]. Such training, based on social interactions, is a source of valuable experience. The effectiveness and degree of social training are determined by the influence of one's social and professional environment $[14,19,20]$.

The effectiveness of this training depends in turn on intellectual disposition, which determines whether socially competent behavior can be cultivated or not. This intellectual disposition is understood here to include emotional and social intelligence, as well as verbal aptitude. The effectiveness of social training, on the other hand, is influenced by a person's temperament and personality - as well as by environmental and educational factors - which motivate the person to become involved in social situations [13, 17-19, 23, 25]. In emphasizing the significance of the social, communicative, and interpersonal competences of physicians, nurses, and paramedics, researchers indicate that high levels of these competences are important predictors of patient satisfaction with healthcare services and the quality of medical care, as well as of patients' adherence to their treatment $[2,5-9,24,26-28]$. They also suggest that medical workers and medical school students need to develop specific competences which are required in various professional and social situations $[2,26,29]$.

Hsu et al. indicated the need to develop specific competences in first-line healthcare workers (physicians, nurses, and paramedics) that are required in catastrophes and natural disasters. Such competences include the abilities to efficiently and critically communicate and to use professional knowledge and skills in performing their professional roles during critical situations [26]. Meretoja et al., on the other hand, underline the need to develop normal nursing competences in nursing students in order to maintain high-quality services in the future $[2,29]$.

Moreover, better social competence among physicians, nurses, and paramedics seems to be a factor that protects them against the symptoms of occupational burnout - it is negatively associated with dimensions such as emotional exhaustion, emotional detachment, and dehumanization, and positively associated with personal accomplishment [30-32]. Social competence appears to be a good predictor of the professional functioning of specialist healthcare workers - for example, in hospices and in positions which require decisions be made, professional and safety standards be maintained, and the outcomes of various actions be predicted $[30,33]$.

It was assumed for the sake of this study that social competence is a set of abilities that determine one's ability to cope in social situations. These abilities are acquired in the process of social training and include, in particular, competence required in intimate situations, involving close interpersonal contact (I); competence needed in situations of social exposure (SE); and competence in situations demanding assertiveness $(A)[14,18$, 20, 23].

The purpose of this study was to determine the level of social competence in three groups of healthcare workers: physicians, nurses, and paramedics. The aim was also to identify the sociodemographic indicators and factors that play a role in the process of social training (length of time working in the profession, workplace, membership of scientific societies and social organizations, and participation in the education of students and workers) that shape social competence.

We sought answers to the following questions: What level of social competence do physicians, nurses, and paramedics have? Which of the selected variables affect this level? What is the relationship between social training and the level of social competence among physicians, nurses, and paramedics?

The literature contains a few studies of social competence and social training that refer to these three professional groups together $[5,7,26]$. Reports concerning the competences of only one professional group are more common: physicians $[3,4,6$,
$8,9,24,32]$, nurses $[1,2,13,27,29-31,34]$, or - more rarely - paramedics $[10,22,33,35,36]$.

The following hypotheses were proposed:

1. There is a relationship between the levels of general social competence and $\mathrm{A}, \mathrm{SE}$, and I competence and variables such as age, gender, education, and current profession. Specifically, male gender, older age, higher education, and being a physician contribute to a higher level of general competence.

2. Social competence is shaped in the process of social training. Higher levels of competence are observed among healthcare workers with more experience in the profession and more seniority in their previous job working in a hospital or emergency ambulance service, and among those who are members of scientific societies or social organizations and are involved in educating students and other social groups.

\section{Material and methods}

\section{Study design}

This was a cross-sectional retrospective study.

\section{Setting and variables}

The study was conducted in Poland in 2015-2016 with the consent of the Bioethical Commission of the Pomeranian Medical University in Szczecin, Poland (KB-0012/92/12/2014). The purposive sampling method was used.

\section{Participants}

Those invited to take part in the study were physicians and nurses from the internal medicine, surgical, and pediatric wards in Szczecin, paramedics providing emergency services in Szczecin, and primary care physicians in Szczecin and Wroclaw. The research was carried out personally by members of the research team. Participation in the study was voluntary. All employees of the selected health care centers had an equal opportunity to take part in the study. A total of 360 questionnaires were distributed, of which 303 were properly filled out and returned; 57 subjects -30 physicians, 8 nurses, and 19 paramedics - chose not to participate in the study. The study involved 303 medical workers from two medical centers (Szczecin and Wroclaw), including 90 physicians (29.7\%), 112 nurses (36.96\%), and 101 paramedics (33.3\%). One hundred respondents (30.3\%) had secondary education, including 51 nurses (45.5\%) and 49 paramedics $(48.5 \%)$. The median age was 38 years (range: 20-66). Detailed sociodemographic data are presented in Table 1 , together with information on their membership in scientific societies and organizations and involvement in the education of students and healthcare workers. Of all the participants, 94 (31\%) were engaged in scientific work, the majority of them being physicians - 38 (40.43\%); $114(37.62 \%)$ respondents -45 physicians (39.47\%), 42 nurses (36.84\%), and 27 paramedics $(23.68 \%)$ - indicated that they were involved in the education of students and workers.

\section{Data sources}

Levels of social competence were measured using the Social Competence Questionnaire (SCQ) developed by Matczak [14]. This is a self-reported instrument consisting of 90 items, including 60 diagnostic items (concerning social competence) and 30 non-diagnostic items (concerning other abilities). The total score for the diagnostic items is a general indicator of social competence. Individuals assess their effectiveness in performing tasks ("How well would you manage if ...?") using a four- 


\begin{tabular}{|c|c|c|c|c|c|c|c|c|c|c|}
\hline \multicolumn{2}{|l|}{ Variable } & \multicolumn{2}{|l|}{ Total } & \multicolumn{2}{|c|}{ Physicians } & \multicolumn{2}{|c|}{ Nurses } & \multicolumn{2}{|c|}{ Paramedics } & \multirow{2}{*}{\begin{tabular}{|l}
$* H{ }^{* *} \chi^{2}$ \\
$p$
\end{tabular}} \\
\hline & & $n$ & $\%$ & $n$ & $\%$ & $n$ & $\%$ & $n$ & $\%$ & \\
\hline \multicolumn{2}{|l|}{ Total } & 303 & 100.0 & 90 & 29.7 & 112 & 37.0 & 101 & 33.3 & \\
\hline \multirow[t]{2}{*}{ Gender } & female & 192 & 63.4 & 60 & 31.3 & 106 & 55.2 & 26 & 13.5 & $* * 109.21$ \\
\hline & male & 111 & 36.6 & 30 & 27.0 & 6 & 5.4 & 75 & 67.6 & $<0.001$ \\
\hline \multirow{6}{*}{$\begin{array}{l}\text { Place of residence } \\
\text { (population) }\end{array}$} & rural area & 31 & 10.2 & 6 & 19.4 & 9 & 29.0 & 16 & 51.6 & $* * 51.57$ \\
\hline & town: $<5,000$ & 8 & 2.6 & 1 & 12.5 & 3 & 37.5 & 4 & 50.0 & $<0.001$ \\
\hline & town: $5,000-10,000$ & 14 & 4.6 & 1 & 7.1 & 5 & 35.7 & 8 & 57.1 & \\
\hline & city: $10,000-50,000$ & 49 & 16.2 & 6 & 12.2 & 17 & 34.7 & 26 & 53.1 & \\
\hline & city: $50,000-100,000$ & 32 & 10.6 & 14 & 43.8 & 8 & 25.0 & 10 & 31.3 & \\
\hline & city: $>100,000$ & 169 & 55.8 & 62 & 36.7 & 70 & 41.4 & 37 & 21.9 & \\
\hline \multirow[t]{4}{*}{ Workplace } & primary care center & 30 & 9.9 & 25 & 83.3 & 5 & 16.7 & 0 & 0.0 & $* * 71.64$ \\
\hline & hospital & 165 & 54.5 & 46 & 27.9 & 95 & 57.6 & 24 & 14.5 & $<0.001$ \\
\hline & emergency department & 79 & 26.1 & 8 & 10.1 & 2 & 2.5 & 69 & 87.3 & \\
\hline & other healthcare centers & 29 & 9.6 & 11 & 37.9 & 10 & 34.5 & 8 & 27.6 & \\
\hline \multirow{2}{*}{$\begin{array}{l}\text { Social and scientific } \\
\text { activity }\end{array}$} & yes & 94 & 31.0 & 38 & 40.4 & 25 & 26.6 & 31 & 33.0 & $* * 9.24$ \\
\hline & no & 209 & 69.0 & 52 & 24.9 & 87 & 41.6 & 70 & 33.5 & 0.01 \\
\hline \multirow{2}{*}{$\begin{array}{l}\text { Teaching activity: } \\
\text { educating students, } \\
\text { preparing and con- } \\
\text { ducting courses }\end{array}$} & yes & 114 & 37.6 & 45 & 39.5 & 42 & 36.8 & 27 & 23.7 & $* * 10.98$ \\
\hline & no & 189 & 62.4 & 45 & 23.8 & 70 & 37.0 & 74 & 39.2 & 0.004 \\
\hline \multicolumn{2}{|l|}{ Variable } & \multicolumn{2}{|l|}{ Total } & \multicolumn{2}{|c|}{ Physicians } & \multicolumn{2}{|c|}{ Nurses } & \multicolumn{2}{|c|}{ Paramedics } & $\begin{array}{l}* H \text { or } \\
{ }^{* *} \chi^{2} ; p\end{array}$ \\
\hline \multirow[t]{5}{*}{ Age } & median & \multicolumn{2}{|l|}{38} & \multicolumn{2}{|c|}{31.5} & \multicolumn{2}{|l|}{44} & \multicolumn{2}{|l|}{28} & $* 58.24$ \\
\hline & $\min$. & \multicolumn{2}{|l|}{20} & \multicolumn{2}{|l|}{24} & \multicolumn{2}{|l|}{22} & \multicolumn{2}{|l|}{20} & $<0.001$ \\
\hline & max. & 66 & & 66 & & 61 & & 56 & & \\
\hline & $\mathrm{Q}_{1}$ & 27 & & 28 & & 39 & & 24 & & \\
\hline & $\mathrm{Q}_{3}$ & 47 & & 47 & & 50 & & 37 & & \\
\hline Time in the profes- & median & 13 & & 4 & & 22 & & 7.5 & & *64.92 \\
\hline sion (years) & $\min$. & 0.5 & & 1 & & 1 & & 0.5 & & $<0.001$ \\
\hline & max. & 42 & & 40 & & 42 & & 37 & & \\
\hline & $\mathrm{Q}_{1}$ & 3 & & 2 & & 17.25 & & 2 & & \\
\hline & $\mathrm{Q}_{3}$ & 25 & & 20 & & 29 & & 15 & & \\
\hline Time in previous & median & 7 & & 3 & & 12 & & 4 & & *36.36 \\
\hline job (years) & $\min$. & 1 & & 1 & & 1 & & 1 & & $<0.001$ \\
\hline & $\max$. & 42 & & 34 & & 42 & & 37 & & \\
\hline & $\mathrm{Q}_{1}$ & 2 & & 1 & & 6 & & 1 & & \\
\hline & $\mathrm{Q}_{3}$ & 15 & & 7 & & 20 & & 12 & & \\
\hline
\end{tabular}

${ }^{*} H-$ Kruskal-Wallis test value; ${ }^{* *} \chi^{2}-$ Pearson's test for independence; $p$ - level of significance.

point scale: "very well," "quite well," "rather poorly," or "very badly". The total score is the sum of the scores for the diagnostic items. The diagnostic items were based on the classification of difficult social situations proposed by Argyle. Four types of situations were distinguished: 1 ) intimate situations (I), which refer to close interpersonal contact; 2) social exposure situations (SE); 3) formal situations, which require one to adapt to strictly defined rules or regulations; and 4) situations which demand assertiveness (A) [12].

Based on the factor analysis, three out of the four social scales were included in the final version of the questionnaire. The I scale: this refers to the competence which determines the effectiveness of behaviors in situations of close interpersonal contact with patients, listening to patients while showing understanding of and empathy for their fears and tolerance for their impatience and dissatisfaction with therapeutic outcomes. This scale contains 15 items; the minimum score is 15 points, and the maximum is 60 points. The SE scale, which refers to being an object of attention and potential appraisal from many people, includes 18 items and has a range of scores from 18 points to a maximum of 72 points. The A scale, which refers to attaining one's own goals and satisfying one's needs through persuasion, as well as the ability to influence and resist the influence of others, includes 17 items, ranging in scores from 17 points to a maximum of 68 points.

The point scores were converted into sten scores: a sten of 1-3 was considered a low score, 4-7 was considered an average score, and 8-10 was considered a high score [6].

\section{Statistical analysis}

The type of distribution was determined for quantitative variables. The Shapiro-Wilk test was employed to verify the normality of these distributions. Arithmetic means, standard deviations, medians, and ranges of variability (extremes) were calculated for the measurable (quantitative) variables, while frequencies (percentages) were determined for qualitative vari- 
ables. The following statistical tests were applied, depending on the distribution of the variable: Kruskal-Wallis $(H)$, Mann-Whitney $U$-test ( $Z$-score), Pearson's test for independence $\left(\chi^{2}\right)$, Pearson's linear correlation $(r)$, or ANOVA $(F)$. Logistic regression was used to determine the influence of explanatory variables on the odds ratio (OR) of having higher social competence, with a $95 \%$ confidence interval. The level of significance for all tests was set at $1-\alpha=0.95 ; \alpha=0.05$. Statistical analysis was carried out using PASW Statistics v. 18 software.

\section{Results}

The majority of the healthcare workers $(62.4 \% ; 189)$ had average general social competence (a sten of 4-7), and $15.8 \%$ (48) had low competence (a sten of 1-3) (Table 2).

We compared the levels of general competence and of I, $A$, and SE competences between professional groups. Statistically significant differences were only found in the levels of A competence between physicians, nurses, and paramedics
$(H=17.32 ; p<0.001)$. Higher A competence levels were observed among paramedics (Table 3 ). There was a significant relationship between gender and levels of competence: women had higher I and SE competences $(p=0.002)$, while men had higher A competence $(p=0.0001)$. Older respondents had lower general competence $(r=-0.13 ; p=0.03)$, lower I competence $(r=-0.16 ; p=0.01)$, and lower SE competence $(r=-0.14 ; p=0.01)$. In nurses, age correlated negatively with general competence $(r=-0.26 ; p=0.006)$ and with I, SE, and A competence. The older the nurses were, the lower their social competence was.

\section{Social training}

Statistically significant relationships were observed between scientific or social activity and the level of SE competence. Those respondents who are members of scientific societies had higher levels of SE competence $(Z=-2.35 ; p=0.02$; Table 4). Nurses who had been employed longer in their last job had lower SE competence $(r=-0.23 ; p=0.04)$.

\begin{tabular}{|c|c|c|c|c|c|c|c|c|c|c|c|c|c|c|c|c|}
\hline \multirow{3}{*}{$\begin{array}{l}\text { Competence } \\
\text { scales ac- } \\
\text { cording to } \\
\text { the SCQ }\end{array}$} & \multicolumn{5}{|c|}{ Raw values } & \multicolumn{5}{|c|}{ Sten scores } & \multicolumn{6}{|c|}{ Competence levels as sten scores, $n(\%)$} \\
\hline & \multirow[t]{2}{*}{$\begin{array}{l}\text { Me- } \\
\text { dian }\end{array}$} & \multirow[t]{2}{*}{ Min. } & \multirow[t]{2}{*}{ Max. } & \multirow[t]{2}{*}{$\mathbf{Q}_{1}$} & \multirow[t]{2}{*}{$Q_{3}$} & \multirow[t]{2}{*}{$\begin{array}{l}\text { Me- } \\
\text { dian }\end{array}$} & \multirow[t]{2}{*}{ Min. } & \multirow[t]{2}{*}{ Max. } & \multirow[t]{2}{*}{$Q_{1}$} & \multirow[t]{2}{*}{$\mathbf{Q}_{3}$} & \multicolumn{2}{|c|}{$1-3$ (low) } & \multicolumn{2}{|c|}{$\begin{array}{l}4-7 \text { (aver- } \\
\text { age) }\end{array}$} & \multicolumn{2}{|c|}{ 8-10 (high) } \\
\hline & & & & & & & & & & & $n$ & $\%$ & $n$ & $\%$ & $n$ & $\%$ \\
\hline Total (I) & 43 & 22 & 60 & 39 & 48 & 6 & 1 & 10 & 4 & 7 & 51 & 16.8 & 182 & 60.1 & 70 & 23.1 \\
\hline Total (SE) & 53 & 25 & 72 & 46 & 60 & 5 & 1 & 10 & 4 & 7 & 72 & 23.8 & 168 & 55.4 & 63 & 20.8 \\
\hline Total (A) & 48 & 26 & 68 & 44 & 54 & 5 & 1 & 10 & 4 & 7 & 44 & 14.5 & 203 & 67.0 & 56 & 18.5 \\
\hline Total SCQ & 178 & 106 & 158 & 178 & 194 & 6 & 1 & 10 & 4 & 7 & 48 & 15.8 & 189 & 62.4 & 66 & 21.8 \\
\hline
\end{tabular}

The scales represent the competence that determines effective behaviors in I- intimate situations; SE - social exposure situations; or A - situations requiring assertiveness.

\begin{tabular}{|c|c|c|c|c|c|c|c|c|c|c|c|c|}
\hline \multirow{2}{*}{$\begin{array}{l}\text { SCQ } \\
\text { scales }\end{array}$} & \multicolumn{3}{|c|}{ I scale } & \multicolumn{3}{|c|}{ SE scale } & \multicolumn{3}{|c|}{ A scale } & \multicolumn{3}{|c|}{ Total SCQ } \\
\hline & GP & $\mathbf{N}$ & $\mathbf{P}$ & GP & $\mathbf{N}$ & $\mathbf{P}$ & GP & $\mathbf{N}$ & $\mathbf{P}$ & GP & $N$ & $P$ \\
\hline$n$ & 90 & 112 & 101 & 90 & 112 & 101 & 90 & 112 & 101 & 90 & 112 & 101 \\
\hline$\%$ & 29.7 & 36.96 & 33.33 & 29.7 & 36.96 & 33.33 & 29.7 & 36.96 & 33.33 & 29.7 & 36.96 & 33.33 \\
\hline Median & 6 & 6 & 5 & 5 & 5 & 6 & 5 & 5 & 6 & 6 & 5 & 6 \\
\hline Min. & 1 & 1 & 1 & 1 & 1 & 1 & 1 & 1 & 1 & 1 & 1 & 1 \\
\hline Max. & 10 & 10 & 10 & 10 & 10 & 10 & 10 & 10 & 10 & 10 & 10 & 10 \\
\hline $\mathrm{Q}_{1}$ & 4.00 & 4.00 & 4.00 & 4.00 & 4.00 & 3.00 & 4.00 & 4.00 & 5.00 & 4.00 & 4.00 & 5.00 \\
\hline $\mathrm{Q}_{3}$ & 7.00 & 7.00 & 7.00 & 7.00 & 7.00 & 7.00 & 6.25 & 7.00 & 8.00 & 7.00 & 7.00 & 7.00 \\
\hline $\mathrm{F} / \mathrm{H}^{*}$ & \multicolumn{3}{|c|}{$0.069 *$} & \multicolumn{3}{|c|}{$0.031 *$} & \multicolumn{3}{|c|}{$17.32 *$} & \multicolumn{3}{|l|}{2.60} \\
\hline$p$ & \multicolumn{3}{|l|}{0.96} & \multicolumn{3}{|c|}{0.985} & \multicolumn{3}{|c|}{0.0001} & \multicolumn{3}{|l|}{0.27} \\
\hline
\end{tabular}

F-ANOVA test value; $H^{*}-$ Kruskal-Wallis test value; $p$ - level of significance; GP-general practitioner; $\mathrm{N}-$ nurse; $\mathrm{P}-$ paramedic.

The scales represent competences which determine effective behaviors in I - intimate situations; SE - social exposure situations; or A - situations requiring assertiveness.

\begin{tabular}{|c|c|c|c|c|c|}
\hline \multirow[t]{2}{*}{ Variables } & \multirow{2}{*}{$\begin{array}{l}\text { Test } \\
p\end{array}$} & \multicolumn{4}{|c|}{ Social competence (sten scores) } \\
\hline & & I scale & SE scale & A scale & Total \\
\hline \multirow[t]{2}{*}{ Age } & $r$ & -0.13 & -0.09 & -0.11 & -0.13 \\
\hline & $p$ & 0.03 & 0.11 & 0.06 & 0.03 \\
\hline \multirow[t]{2}{*}{ Gender } & $z$ & -3.09 & -3.08 & -5.25 & -0.21 \\
\hline & $p$ & 0.002 & 0.002 & $<0.001$ & 0.83 \\
\hline \multirow[t]{2}{*}{ Time in profession (years) } & $r$ & -0.08 & -0.03 & -0.05 & -0.05 \\
\hline & $p$ & 0.19 & 0.61 & 0.42 & 0.39 \\
\hline \multirow[t]{2}{*}{ Time in last job (years) } & $r$ & -0.08 & -0.06 & -0.04 & -0.08 \\
\hline & $p$ & 0.28 & 0.38 & \begin{tabular}{|l|}
0.59 \\
\end{tabular} & 0,294 \\
\hline
\end{tabular}




\begin{tabular}{|c|c|c|c|c|c|}
\hline \multirow[t]{2}{*}{ Variables } & \multirow{2}{*}{$\begin{array}{l}\text { Test } \\
p\end{array}$} & \multicolumn{4}{|c|}{ Social competence (sten scores) } \\
\hline & & I scale & SE scale & A scale & Total \\
\hline \multirow[t]{2}{*}{ Teaching activity } & $z$ & -0.12 & -1.65 & -0.72 & -0.04 \\
\hline & $p$ & 0.90 & 0.09 & 0.47 & 0.97 \\
\hline \multirow[t]{2}{*}{ Scientific and social activity } & $z$ & -1.12 & -2.35 & -0.07 & -1.39 \\
\hline & $p$ & 0.26 & 0.02 & 0.95 & 0.17 \\
\hline
\end{tabular}

$r$ - Pearson's linear correlation coefficient; $Z$ - Mann-Whitney U-test Z-score; $p$ - level of significance

\section{Odds ratio}

The OR for higher levels (over 4) of general social competence and of $\mathrm{A}, \mathrm{SE}$, and I competences can be described as follows:

1. Membership in scientific societies and social organizations increases the odds of physicians having higher general competence by a factor of four (OR = 3.47; $95 \% \mathrm{Cl}: 1.34-8.98)$; the percentages of physicians with high levels of general social competence were $83.3 \%$ (answer: yes) and $53.8 \%$ (answer: no) $(p=0.01)$

2. Membership in scientific societies and social organizations increases the odds of physicians having higher competence in social exposure situations by a factor of four (OR $=3.47 ; 95 \% \mathrm{Cl}: 1.42-10.16)$; the percentages of physicians with high levels of ES competence were $80.6 \%$ (answer: yes) and 51.9\% (answer: no) ( $p$ $=0.001$ ).

3. Being involved in the education of medical staff increases the odds of physicians having higher competence in social exposure situations by a factor of three $(\mathrm{OR}=2.69 ; 95 \% \mathrm{Cl}: 1.21-7.24)$; the percentages of physicians with high levels of ES competence were $75 \%$ (answer: yes) and 52.3\% (answer: no) $(p=0.02)$.

4. Being involved in the education of other social groups increases the odds of paramedics having lower I competence by a factor of $0.34(\mathrm{OR}=0.34 ; 95 \% \mathrm{Cl}$ : $0.14-$ -0.88 ); the percentages of paramedics with high levels of I competence were 55.6\% (answer: yes) and $77.8 \%$ (answer: no) $(p=0.03)$.

5. Male physicians have lower odds by a factor of 0.35 of having higher I competence $(\mathrm{OR}=0.34 ; 95 \% \mathrm{Cl}$ : 0.14 -0.86 ) than female physicians do; the percentages of physicians with high levels of I competence were $50 \%$ for men and $73.3 \%$ for women $(p=0.02)$.

6. Male physicians have lower odds by a factor of 0.35 of having higher SE competence $(\mathrm{OR}=0.35 ; 95 \% \mathrm{Cl}$ : 0.14-0.86) than female physicians do; the percentages of physicians with high levels of SE competence were $46.4 \%$ for men and $71.7 \%$ for women $(p=0.02)$.

7. Male paramedics have six times higher odds of having higher A competence ( $O R=6.22 ; 95 \% \mathrm{Cl}: 1.82-21.32$ ) than women do; the percentages of paramedics with high levels of A competence were $93.2 \%$ for men and $68 \%$ for women $(p=0.001)$.

8. Medical workers employed in hospitals and other inpatient centers have four times higher odds of having high A competence than those in primary care centers $(\mathrm{OR}=3.14 ; 95 \% \mathrm{Cl}: 1.46-6.76)$; the percentages of medical workers with high levels of A competence were $75.82 \%$ for those employed in hospitals and other inpatient centers, and $50 \%$ for those in primary care centers $(p=0.004)$

9. Medical workers employed in primary care centers, hospitals, and other inpatient centers have lower odds of having high A competence $(\mathrm{OR}=0.28 ; 95 \% \mathrm{Cl}$ : 0.13 $-0.59)$ than those in emergency departments; the per- centages of medical workers with low levels of A competence were $32 \%$ for those employed in primary care centers, hospitals, and other inpatient centers, and $12 \%$ for those in emergency departments $(p=0.001)$.

10. Medical workers employed in primary care centers, hospitals, and other inpatient centers have lower odds of high general competence $(\mathrm{OR}=0.51 ; 95 \% \mathrm{Cl}$ : $0.8-$ -0.92 ) than those in emergency departments; the percentages of medical workers with low levels of general competence were $36 \%$ for those employed in primary care centers, hospitals, and other inpatient centers, and $22 \%$ for those in emergency departments ( $p=$ $0.026)$.

We can assume, albeit with some uncertainty, that emergency department workers have higher assertive competence than medical workers employed in other healthcare centers.

\section{Discussion}

Professional competent behavior in work situations is one of the pillars of effective healthcare practice [24]. Disease, suffering, and death require social competence from physicians, nurses, and paramedics, so that they can cope with their own emotions in difficult situations and can control the emotions of others-patients and their families, those injured in accidents, and other team members.

Patients in a hospital are in direct contact with medical staff. The relationships between patients and medical staff can be shaped by environmental and situational factors, as well as by individual traits on both sides of the interaction. Studies have shown that positive relationships with other people can significantly contribute to recovery $[7,30,36]$.

An attempt has been made in the current study to estimate the levels of social competence among physicians, nurses, and paramedics and to discover which factors influence these levels. According to our findings, the physicians, nurses, and paramedics presented average levels of general social competence and of $\mathrm{A}, \mathrm{SE}$, and I competences, allowing them to act fairly efficiently in social situations. Tychmanowicz and Kuśpit reported that in their study of 40 individuals (physicians, nurses, and midwives), the majority of respondents (73.7\%) had an average level of SC [22]. Gadecka et al. also obtained similar results. Most nurses in their study displayed at least an average level of social competence [27]. Bryl et al. evaluated the effects of physicians' social competence on the level of patient compliance with pharmacological recommendations for osteoporosis treatment. They demonstrated that most physicians showed average levels of general competence and of A, SE, and I competences. According to the authors, when physicians' competence in close emotional contact (I) was high, only $15 \%$ of the patients revealed symptoms of fear of the disease or treatment, in comparison to $40 \%$ of patients when the competence of the physician was low [8]. Other authors have claimed that patients' knowledge of the disease and treatment, and their adherence to the physician's or nurse's instructions, are related to the level of social competence of the medical workers $[7,8,10]$. 
SE and A competences are also essential for effective communication with other workers. These types of competences may contribute to the effectiveness of therapeutic and nursing processes, to the ability to provide medical aid at the site of an accident, and to the quality of interactions within professional groups. One of the social competences analyzed in this study involves ways of dealing with intimate situations. During their conversations with physicians, nurses, and paramedics, patients often raise personal and intimate issues. Such situations require delicacy, sensitivity, and empathy from medical workers.

Combining closeness and intimacy with professionalism is a challenge faced by every physician, nurse, and paramedic [22]. Effective practice requires the ability to identify emotions and to respond in an appropriate way when dealing with patients and their families. Hence, emotional competence (I and A competences) seems to be a key element of professional medical workers' practice [29]. It is therefore very worrying that a relatively large proportion $(15.8 \%)$ of the respondents had a low level of general social competence. Nearly one-fourth $(23.8 \%)$ of the participants had a low level of competence in social exposure situations (SE) and a low level of competence in intimate situations (I), while $14.5 \%$ had a low level of competence in situations demanding assertiveness (A). These results may suggest difficult interpersonal relationships within the team and may indicate disturbed communication with patients. Similar results were obtained by Tychmanowicz and Kuśpit. In their study, medical workers (physicians, nurses, and midwives) presented the lowest levels of competence in intimate situations (I) and situations requiring assertiveness $(A)$ [22].

Our study showed that being an educator has no influence on the level of social competence; the variables that did affect this were age, gender, current profession, and place of work. Women presented higher levels of competence in intimate and social exposure situations, while men were more assertive. Paramedics had considerably higher assertive competence than physicians and nurses. Primary care physicians and nurses, on the other hand, had lower assertive competence than medical workers employed in other healthcare institutions. These results are worrying, as worse relationships between primary care workers and patients mean low patient satisfaction in terms of their needs being met and patient dissatisfaction with medical services, which leads to higher utilization of specialist medical care $[8,27,36]$. The low assertive competence of primary care physicians and nurses may have a negative impact on patients' adherence to therapy and their acceptance of illness [8].

We found that older nurses had low levels (sten scores below 4) of general competence and of A, ES, and I competences. The fact that the mean age of Polish nurses in 2016 was 49 years shows that this is a large group of medical workers whose low level of competence hinders the provision of high-quality services. It can also cause negative work-related experiences and symptoms of burnout syndrome [33].

We have made the assumption that social training has a profound influence on shaping the level of social competence among physicians, nurses, and paramedics. Social competence is acquired in the workplace, through the process of educating medical staff and social groups, and through scientific and organizational activity. We found evidence that higher levels of physicians' competence in social exposure (SE) situations - where they may be objects of attention and potential appraisal - is associated with social training, such as educating students and preparing and delivering courses. It is worrying that nurses who have worked longer in their previous jobs show lower competence in social exposure situations.

The nature of the profession of paramedics is that medical aid is provided in emergency situations, which requires a combination of current clinical knowledge and practical skills. Paramedics often work under time and environmental pressure, and under diverse conditions [22]. However, very few studies have been conducted so far on paramedics' ability to cope with emotions and their level of competence. In our study, paramedics showed higher competence in situations demanding assertiveness (A) than physicians and nurses, and average competence in situations involving close interpersonal contact (I) and social exposure (ES). Similarly, in a study conducted by WłoszczakSzubzda et al. on paramedics and students, paramedics presented a low level of communicative and active listening competence (I), which may considerably hinder their performance at the scene of an accident [28]. Another study of 100 professionally active paramedics aged 20-60 years found that the paramedics took part in in-service training courses, but that this form of social training did not visibly change the level of their knowledge [37].

High competence levels among paramedics and nurses contribute to their high professional and social positions, as it enables them to provide medical care in critical situations which require a special predisposition [26, 30, 35]. However, it will not be possible for medical workers to achieve the levels of social and professional competence expected of them if medical school programs do not devote more time to developing the ability to communicate with various social groups, as this is a key activity in medical practice $[28,33,38]$. A good solution for developing social competence in medical workers is to include compulsory interpersonal communication courses in undergraduate education programs in Poland.

\section{Limitations of the study}

The sample size of 303 healthcare workers may not have been adequate for generalizing the findings on a national level.

\section{Conclusions}

The social competence results of the physicians, nurses, and paramedics in our study are low or average, which indicates a need for social training - particularly for engaging professionals in scientific and educational activity.

The results presented in this study may provide some idea of the social competence of medical personnel to those who manage their education, and thus enable them to take steps towards providing healthcare workers with the social abilities necessary for their professional and social success.

\section{Recommendations}

The results presented in this article identify deficits in the competence required in medical professions, and can serve as a basis for further research in this field.

Source of funding: This work was funded from the authors' own resources.

Conflicts of interest: The authors declare no conflicts of interest.

\section{References}

1. Watson R, Stimpson A, Topping A, et al. Clinical competence assessment in nursing: a systematic review of the literature. J Adv Nursing 2002; 39(5): 421-431.

2. Meretoja R, Isoaho H, Leino-Kilpi H. Nurse Competence Scale: development and psychometric testing. J Adv Nursing 2004; 47(2): 124-133. 
3. Derkacz M, Chmiel-Perzyńska I, Kowal A, et al. Rozumienie zaleceń lekarskich - niedoceniany problem w codziennej praktyce lekarza rodzinnego. Fam Med Prim Care Rev 2010; 12(3): 618-621 (in Polish).

4. Yanhua C, Watson R. A review of clinical competence assessment in nursing. Nurse Educ Today 2011; 31(8): 832-836.

5. Zayapragassarazan Z, Kumar S. Emotional intelligence and medical professionalism. NTTC Bull 2011; 18(2): 3-4.

6. Kostadinova I, Antonova D. Integrated system for improving professional competence taking into account the impact of emotional and social intelligence on doctors' practice. Analele Universitatii 'Eftimie Murgu' Resita. Fascicola II. Studii Economice; 2014. Available from URL: http://www.analefseauem.ro/upload/arhiva-revista/2014/Volum_2014.pdf.

7. Motyka M. Rola aktywnego słuchania w komunikacji terapeutycznej z pacjentem. Probl Pielęg 2011; 19(2): $259-265$ (in Polish).

8. Bryl N, Horst-Sikorska W, Ignaszak-Szczepaniak M, et al. Influence of social competence of physicians on patient compliance with osteoporosis medications - a study on Polish postmenopausal women. Ginekol Pol 2012; 83(7): 511-516.

9. Jankowska K, Pasierski T. Medical communication: a core medical competence. Pol Arch Med Wewn 2014; 124(7-8): 350-351, doi: 10/ AOP_14_046.

10. Tavares $\mathrm{W}$, Boet $\mathrm{S}$, Theriault $\mathrm{R}$, et al. Global rating scale for the assessment of paramedic clinical competence. Prehosp Emerg Care 2012; 4, doi: 10.3109/10903127.2012.702194.

11. White RW. Motivation reconsidered: the concept of competence. Psychol Rev 1959; 66(5): 297-333.

12. Argyle M. The psychology of interpersonal behaviour. 5th ed. Harmondsworth: Penguin; 1994.

13. O'Leary J. Comparison of self-assessed competence and experience among critical care nurses. J Nurs Manag 2012; 20(5): 607-614.

14. Matczak A. Kwestionariusz Kompetencji Społecznych. 2nd ed. Warszawa: Pracownia Testów Psychologicznych Polskiego Towarzystwa Psychologicznego; 2012 (in Polish).

15. Puteh F, Kaliannan M, Alam N. Employee core competencies and organisational excellence: an interpretative analysis. AJBES 2016; 2(1): 45-55.

16. Grandey AA. Emotion regulation in the workplace: a new way to conceptualize emotional labor. J Occupational Health Psychol 2000; 5: 95-110.

17. Szczygieł D, Bazińska R, Kadzikowska-Wrzosek R, et al. Praca emocjonalna w zawodach usługowych - pojęcie, przegląd teorii i badań. Psychol Społ 2009; 4(11): 155-156 (in Polish).

18. Bobrowska-Jabłońska K. Znaczenie inteligencji emocjonalnej $\mathrm{i}$ kompetencji społecznych w kształceniu w SGH - raport z badań. E-mentor 2003; 2: 22-27 (in Polish).

19. Tomorowicz A. Struktura kompetencji społecznych w ujęciu interakcyjnym. Psychiatria 2011; 8(3): 91-96 (in Polish).

20. Martowska K. Psychologiczne uwarunkowania kompetencji społecznych. Warszawa: Liberi Libri; 2012 (in Polish).

21. Elias MJ. The connection between academic and social-emotional labor. Available from URL: http://www.ekero.se/Global/Uppleva_ och_gora/Ung_i_Ekero/Elias,\%20The\%20connection\%20between\%20adademic\%20and\%20social\%20emotional\%20lerarning.pdf.

22. Tychmanowicz A, Kuśpit M. Social competences of health service workers. Pilot study. Prog Health Sci 2012; 2(1): 107-112.

23. Martowska K. Temperamental determinants of social competencies. Pol Psychol Bull 2014; 45(2): 128-133, doi: 10.2478/ppb-20140017.

24. Lindberg O, Rantatalo O. Competence in professional practice: a practice theory analysis of police and doctors. Hum Relat 2015; 68(4): 561-582.

25. Smółka P, Szulawski M. Personality traits and motivational traits as predictors of social competence. Implication for occupational selection process. Edukacja Ekonomistów i Menedżerów 2011; 22(4): 111-126.

26. Hsu EB, Thomas TL, Bass EB, et al. Healthcare worker competencies for disaster training. BMC Med Educ 2006; 6: 9, doi: 10.1186/14726920-6-19.

27. Gadecka W, Piskorz-Ogórek K, Regin KJ, et al. Social competence of mental health nurses. Polish Annals of Medicine 2015; 22(2): 105-109.

28. Włoszczak-Szubzda A, Jarosz JM, Goniewicz M. Professional communication competences of paramedics - practical and educational. Ann Agric Environ Med 2013; 20(2): 366-372.

29. Wilson SC, Carryer J. Emotional competence and nursing education: a New Zealand study. Nurs Prax N Z 2008; 24(1): 36-47.

30. Riggio RE, Taylor SJ. Personality and communication skills as predictors of hospice nurse performance. J Bus Psychol 2000; 15(2): 251-359.

31. Kuokkanen L, Leino-Kilpi H. The qualities of an empowered nurse and the factors involved. J Nurs Manag 2001; 9: 273-280.

32. Pereira-Lima K, Loureiro SR. Burnout, anxiety, depression, and social skills in medical residents. Psychol Health Med 2015; 20(3): 353-362.

33. Wnukowski K, Kopański Z, Sianos G. Specyfika pracy ratownika medycznego. J Clin Health 2015; 3: 2-9 (in Polish).

34. Blazun H, Kokol P, Vosner J. Survey on specific nursing competences: students' perceptions. Nurse Educ Pract 2015; 15: 359-365.

35. Evans R, McGovern R, Birch J, et al. Which extended paramedic skills are making an impact in emergency care and can be related to the UK paramedic system? A systematic review of the literaturę. Emerg Med J 2014; 31(7): 594-603.

36. Kurpas D, Wróblewska I, Kassolik K, et al. Unmet needs of patients with chronic respiratory diseases within primary healthcare. Advs Exp Medicine Biology Neuroscience Respiration 2015; 14: 43-55.

37. Leszczyński P. Analiza kompetencji zawodowych ratowników medycznych w wybranych jednostkach ratowniczych. Edukacja Ustawiczna Dorosłych 2013; 4(83): 71-82 (in Polish).

38. Henry SG, Holmboe ES, Frankel RM. Evidencebased competencies for improving communication skills in graduate medical education: a review with suggestions for implementation. Med Teach 2011; 35(5): 395-403.

Tables: 4

Figures: 0

References: 38

Received: 28.11.2019

Reviewed: 30.11 .2019

Accepted: 21.12.2019
Address for correspondence:

Halina Brzeźniak, PhD

Zakład Nauk Humanistycznych w Medycynie

Pomorski Uniwersytet Medyczny w Szczecinie

ul. Gen. D. Chłapowskiego 11

70-193 Szczecin

Polska

Tel.: +48 509 949-619

E-mail: halina.brzezniak@pum.edu.pl 